RESEARCH ARTICLE

\title{
POPULATION GROWTH CONTROL POLICY AND ITS EFFECT TO LAW ENFORCEMENT
}

\author{
Sinta Oktavina ${ }^{l_{\varpi}}$ \\ ${ }^{1}$ Postgraduate Program, Master of Laws, Universitas Negeri Semarang, Indonesia \\ $\bowtie$ oktavina.epaso@gmail.com
}

\section{CITED AS}

Oktavina, S. (2020). Population Growth Control Policy and Its Effect to Law Enforcement. Journal of Law and Legal Reform, 1(2), 225-240. DOI: https://doi.org/ 10.15294/jllr.vli2.35460

\section{ABSTRACT}

In minimizing population growth that occurs in Indonesia one of them can be done with a family planning program (KB) that has been carried out by the government. In accordance with the framework and ideals of the Indonesian people listed in the opening of the 1945 Constitution. The purpose of the study was to describe the implementation of improving population control through family planning programs in Semarang District in terms of Article 4 Paragraph (l) of the Central Java Regional Regulation No. 6 of 2013 and Knowing the supporting and inhibiting factors in overcoming population control through family planning programs in Semarang Regency. This legal research method uses a qualitative approach with a type of sociolegal research. The results of the study were obtained that (1) The implementation of family planning programs in Semarang Regency was carried out well from the central level to the field. The Office of PP, PA, and KB carry out regulations related to family planning programs which are the vision of the Regent. By communicating, providing information and education to the community and providing socialization and coordination in the implementation of family planning. (2) The supporting factor is the regulation on the implementation of family planning; there is reliable medical personnel. As for the inhibiting factors, not all communities accept the existence of a family planning program; community culture that is still strongly attached to each individual community. The conclusion is that the success of family programs goes very well and cannot be separated from community participation. So that it can be seen from the number of babies born can be reduced from 14,127 in 2015 and 13,328 in 2016 which are spread from 19 districts in Semarang Regency.

Keywords: Family Planning, Implementation, Control 


\section{TABLE OF CONTENTS}





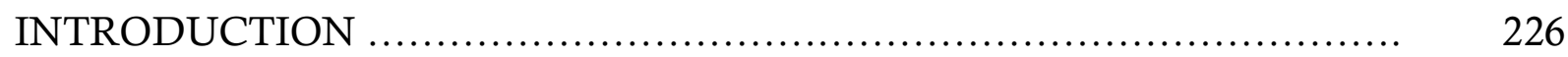



POPULATION CONTROL POLICY (CASE OF CENTRAL JAVA,

INDONESIA) ....................................................... 228

I. IMPLEMENTATION OF IMPROVEMENT OF POPULATION

CONTROL THROUGH THE FAMILY PLANNING .................... 228

II. COMMUNICATION, INFORMATION AND EDUCATION ............... 229

III. INCREASED COMMUNITY INTEGRATION AND ROLES ............. 230

FACTORS IN TACKLING POPULATION CONTROL THROUGH

FAMILY PLANNING PROGRAMS IN SEMARANG REGENCY ........... 234

I. SUPPORTING FACTORS IN TACKLING POPULATION CONTROL

THROUGH FAMILY PLANNING PROGRAMS IN SEMARANG

REGENCY .............................................................

II. INHIBITING FACTORS IN OVERCOMING POPULATION

CONTROL THROUGH FAMILY PLANNING PROGRAMS IN

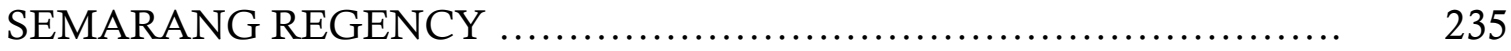

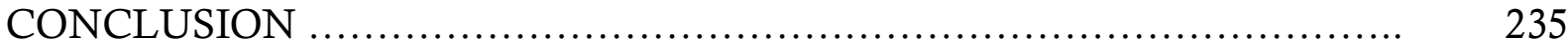

REFERENCES ......................................................... 236

\section{INTRODUCTION}

As an archipelago, the population of Indonesia has an uneven distribution. This causes population growth to be closely linked and affects various aspects of life, especially improving the quality of life or the quality of human resources (Asshiddiqie, 2005). In Article 26 paragraph 2 of the 1945 Constitution states that "Residents are Indonesian citizens and foreigners residing in Indonesia".

For this reason, the Government is trying to make regulations relating to tackling population growth which continues to grow (Ataullahjan, Mumtaz, \& Vallianatos, 2019). The population problem related to the large number of the population becomes an unavoidable problem and becomes one of the problems that really attracts the attention of the government to be immediately addressed (Barroso, 2015). In 1992 the government made laws and regulations namely Law No. 10 of 1992 concerning Development of Population and Family Welfare Development which was later updated with Law No. 52 of 2009. Article 2 states that "Population is a matter relating to the number, structure, growth, distribution, mobility, distribution, quality, and welfare conditions relating to politics, economy, social culture, religion and the environment of the local population."

In the Semarang District alone at the end of 2016, the total population recorded was 1,005,677 people consisting of 503,539 people (51\%) male population and 502,138 
people (49\%) female population. The more population, the more marriages are carried out, and the more marriages that are carried out, the more children are born so that an increasing population growth rate (Ritonga, 2001). For this reason, it is necessary to carry out population control in order to reduce the increasing population, so that the regional government also makes Central Java Provincial Regulation No. 6 of 2013 concerning Population Control and Family Planning Organization. With the large population that occurs resulting in various complex problems that often occur so often the government must act as soon as possible to take a policy. (Masiano, Green, Dahman, \& Kimmel, 2019) Population growth can be seen as a supporting factor for development because population growth also means an increase in labor that can increase production and expand markets (Loyola Briceno et al., 2017). While on the one hand population growth is one of the inhibiting factors.

So from this data, the Indonesian government must take action in order to minimize the very high population growth. One effort that can be done is to maximize the role of competent agencies or agencies in dealing with population growth (Kelsen, 2010). In the process of minimizing population growth, it must be done in several stages that have been formatted so well that it can be carried out and run well because at any time population growth can change (Tran et al., 2019). To minimize population growth in Indonesia, one can be done with family planning (KB) programs that have been carried out by the government (Woo, Alamgir, \& Potter, 2016). The family planning population program is also a means to achieve a just and prosperous and prosperous society. In accordance with the framework and aspirations of the Indonesian people listed in the preamble to the 1945 Constitution. To achieve these goals a development framework including a population planning program was formulated (Brunson, 2019).

\section{METHOD}

The research approach used in this study is a qualitative approach in which the researcher tries to explain and describe each object that is examined is tentative in the context of time and certain situations (Moleong, 2012). The truth of the research results is more supported through trust-based on confirmation with the parties studied. This type of research used in this study is a sociological juridical nondoctrinal approach, namely the study of law using a legal and social science approach (Shidarta, 2011). The focus of his research is on how the implementation of increasing population control through the KB program in Semarang Regency and what factors influence it. The location of data collection is at the Office of Women's Empowerment, Child Protection and Family Planning in Semarang Regency and the Semarang Regency Population and Civil Registry Office. Data sources used are primary, secondary and tertiary data sources (Soekanto, 1986). The data collection techniques that I use are interviews and literature studies. The validity of the data that I use is the triangulation method (Yuliyanto, 2009). Analysis of the data used by Interactive Analysis Models by Huberman and Miles (Suratman, 2013). 


\section{POPULATION CONTROL POLICY (CASE OF CENTRAL JAVA, INDONESIA) \\ I. IMPLEMENTATION OF IMPROVEMENT OF POPULATION CONTROL THROUGH THE FAMILY PLANNING}

Central Java regional government as an autonomous region made Central Java Regional Regulation No. 6 of 2013 concerning Population and Family Planning Control. The background for the formation of this Regional Regulation is that the family as the smallest unit in society has an important role in regional development, therefore it is necessary to develop and develop its quality so that it can always be a prosperous family and be an effective human resource for regional development (Mohan \& Shellard, 2014), especially in the Regency Semarang. To analyze whether local regulations made can be accepted well by the community must also see what elements influence the formation and enforcement (E. Miller et al., 2016). According to Robert B. Seidman, there are three factors that influence the enactment of the law. Seidman's model approach rests on its function of law, being in a balanced state. This means that the law will be able to work well and effectively in the society it governs (G. Miller \& Babiarz, 2015). It is hoped that all three elements must function optimally. Observing the effectiveness of the law and the operation of the law in society needs to pay attention to the following matters: (Nalwadda, Namutebi, \& Volgsten, 2019)

1) Regulatory institutions; whether this institution is an authority or legitimacy in making rules or laws. Related to the quality of normative material, whether it meets the requirements and the formulation is clear (Segrott et al., 2017).

2) The importance of implementing regulations; the executor must strictly implement the law's order without discrimination or equal justice under law (Rogers, Silva, Benatar, \& Briceno, 2018).

3) Role holder; expected to obey the law, ideally with the quality of internalization. Stakeholder behavior and reactions are feedback to regulatory bodies and the implementation of regulations. Whether these two elements have performed their functions optimally (Sonalkar, Mody, \& Gaffield, 2014).

These three elements called the law-making process; law enforcement process; and legal users, it is very important to assess the functioning of the law or the operation of the law in society. The law is expected to function optimally, and work well in society, and must be taken seriously (Catley-Carlson, 1997). Seidman's model approach rests on its function of law, being in a balanced state. This means that the law will be able to work well and effectively in the society it governs. It is hoped that all three elements must function optimally (Eva, Quinn, \& Ngo, 2015). The implementation of the family planning program in Semarang Regency is carried out by the Office of Women's Protection, Child Protection and Family Planning in collaboration with other parties both government agencies and village cadres appointed by the Village Head by: 
1) Establish provisions for the implementation of family planning

To realize a balanced growing population and quality family, the Governor established a family planning policy through the implementation of a family planning program. The family planning policy as referred to in Article 23 of the Central Java Regional Regulation No. 6 of 2013 was implemented to assist candidates or married couples in making decisions and realizing reproductive rights responsibly.

2) Socialization and coordination of the implementation of family planning

The Government in conducting outreach, advocacy, and coordination through improving access and quality of the implementation of population development, family development, and Family Planning services in coordination with the Provincial Government and Regency / City Governments.

In order to improve access and quality in the implementation of population development, family development and Family Planning services of the Government and Regional Governments:

a. provide infrastructure and facilities for population development, family development, and family planning services;

b. provide cover; and

c. provide references for participants in family planning who are in need.

Provision of facilities and infrastructure for the implementation of population development, family development, and Family Planning services include:

a. KIE;

b. contraceptive devices and drugs; and

c. Recording and Reporting on Family Planning Services.

Family Planning Efforts are made through (Eslami \& D'Arcangues, 2016)

a. promotion;

b. protection; and / or

c. assistance in accordance with reproductive rights.

\section{COMMUNICATION, INFORMATION AND EDUCATION}

Education Information Communication (IEC) aims to increase knowledge, attitudes, and behavior of the community in order to support the implementation of Family Planning. The objectives of the implementation of IEC includes: $a$. individual; $b$. group of people; and $c$. general public.

IEC is carried out through the delivery of information and / or demonstration of contraceptive devices, drugs, and / or methods. IEC is implemented at the appropriate place and by: $a$. health workers; $b$. family planning counselors; $c$. Family Planning field officers; and $d$. other trained staff. The implementation of IEC is carried out through the efforts of: $a$. Advocacy and mobilization; $b$. counseling; $c$. accompaniment; and $d$. family empowerment.

Advocacy and mobilization is an effort to provide services to the community in the implementation of Family Planning conducted by the Government, Provincial Governments, Regency/City Governments together with individuals, non-government 
organizations, community organizations, professional organizations, and the private sector.

\section{INCREASED COMMUNITY INTEGRATION AND ROLES}

The Government and the Regional Government carry out a comprehensive and integrated Family Planning policy effort. The implementation of a comprehensive and integrated Family Planning policy effort is carried out coordinatively between ministries and non-ministerial government agencies. In organizing Family Planning policy efforts, the Government and Regional Government can involve the participation of the community (Pusat Pendidikan dan Latihan BKKBN, 1980). Community participation in the form of:

1. Family Coaching

Family coaching is carried out in order to support:

a. developing family security and resilience; and

b. implementation of family functions.

2. Family development

Family development accompanied by IEC, provision of facilities and infrastructure; and other coaching efforts. The development of family security and resilience is carried out by forming and developing:

a. fostering family of toddlers and children;

b. fostering adolescent family resilience and fostering Adolescent / Student Reproductive Health Counseling and Information Centers;

c. fostering the resilience of elderly families; and

d. family economic empowerment.

e. Pregnancy Settings

3. Family Planning

Family Planning is carried out with efforts to increase awareness and community participation through: $a$. mature age of marriage; $b$. desired pregnancy settings; $c$. fostering family planning participation; and $d$. increase family welfare.

Efforts to increase awareness and community participation are directed at the growth of awareness, willingness, and ability of the family independently in building small families, happy, and prosperous. Maturing the marriage age is held in the context of civilizing the attitudes and behavior of the people to carry out the marriage in the ideal age of marriage. The ideal age of marriage is considered by taking into account factors including:(Fischer, Royer, \& White, 2018)

a. physical and mental readiness of a person in forming a family;

b. independence of attitude and maturity of one's behavior;

c. health degree including healthy reproduction;

d. knowledge of prosperous family planning; and

e. statutory regulations in force.

Arrangement of pregnancy held in order to increase public awareness in delaying the pregnancy of the first child until the ideal age of childbirth and regulating the distance of birth. The ideal age of childbirth is the age that is determined or 
influenced by factors: $a$. risk of childbirth; $b$. capabilities regarding care for pregnancy, post-delivery, and periods outside of pregnancy and childbirth; $c$. degree of healthy reproductive health; and / or d. mental, social, and economic wealth in the family.

Delaying pregnancy is carried out in the framework of planning the number and distance between child births that are carried out by the couple themselves on the basis of awareness and volunteerism. Delaying the pregnancy is carried out using tools, drugs and / or contraceptive methods that can be accepted by husband and wife according to their choice. , drugs and / or methods of contraception are determined by taking into account the effectiveness and effectiveness, risks to the health and religious values and values that live in society.

According to Roberth B. Seidman in addition to the law made and the law enforced, the law used also determines the success or failure of the operation of the law. The use of law in society has a close relationship with legal awareness in the community itself. It is said that the higher the level of law used in society, the working system of law can be created properly. (Garney et al., 2019) Simply stated, the level of community compliance with the law is one indicator of the operation of the law, in this case the community's perspective on the existence of the Regional Regulation made by Central Java Province No. 6 of 2013 will determine the success in its implementation. Birth is one component of population growth that is increasing the population. The number of births has consequences on the fulfillment of the needs of the baby's growth and development, from the fulfillment of nutrition, maternal and child health care, and in turn requires educational facilities including the fulfillment of employment opportunities.(Carter, 2018)

\begin{abstract}
Birth rates in the past will affect the high and low number of births in the present, so knowledge about fertility and its indicators, including family planning is very useful for policy makers and plans in preparing social development programs, especially related to efforts to improve the welfare of mother children and family development. (Results of an interview with Ms. Sri Redjeki as Head of Data and Information Management)
\end{abstract}

There are four key steps in the success of reducing fertility, namely grassroots participation to reach rural areas, innovative communication to realize the norms of happy and prosperous small families (NKKBS), government and private partnerships, and shifting focus to quality services. "in Semarang Regency, namely:

1. Use grassroots participation to reach rural areas. The government recruited 40,000 field workers and 100,000 volunteers to bring the community to the service area. They were at the village level and the officers and cadres visited house to house to discuss family planning methods, provide counseling, and make referrals to the Puskesmas (Health Center).

2. The government launched an innovative program that utilizes and optimizes all communication channels and channels of family planning campaigns designed to 
bring the changing social norms from the norms of many children to the norms of few children, which are called "small, happy and prosperous family norms so that the norms are institutionalized in Public.

3. Realizing that the government, in this case government service places, might not be able to provide optimal services to fulfill family planning services. On the other hand, there is another potential that needs to be explored, so once again carried out mutual cooperation or partnering with private parties.

4. Since the mid-1990s, the pattern of KB cultivation has not only focused on quantity but has also been directed towards quality of service.

The number of births is defined as the number of live births that occurred at a certain time and in a certain region. Information about the number of births is useful for planning the construction of various facilities needed especially the development of maternal and child health facilities, both for the present and for the future. In addition, data on the number of live births is the basis for the calculation of various other fertility indicators.(X. Wang \& Zhang, 2018) The number of live births recorded at Semarang District Health Office in 2015 was 14,127 people.

Table 1

Number of Birth Rates in 2015

\begin{tabular}{clcccccc}
\hline \multirow{2}{*}{ No } & \multirow{2}{*}{ Sub-Districts } & \multicolumn{3}{c}{ Men } & \multicolumn{2}{c}{ Women } & \multicolumn{2}{c}{ Total } \\
\cline { 2 - 7 } & & $\mathrm{n}$ & $\%$ & $\mathrm{n}$ & $\%$ & $\mathrm{n}$ & $\%$ \\
\hline 1 & Getasan & 349 & 4.85 & 279 & 4.29 & 646 & 4,57 \\
2 & Tengaran & 461 & 6.40 & 435 & 6.28 & 896 & 6,34 \\
3 & Susukan & 328 & 4.56 & 334 & 4.82 & 662 & 4,69 \\
4 & Suruh & 593 & 8.24 & 545 & 7.87 & 1.138 & 8,06 \\
5 & Pabelan & 335 & 4.65 & 310 & 4.48 & 645 & 4,57 \\
6 & Tuntang & 457 & 6.35 & 406 & 5.86 & 863 & 6,11 \\
7 & Banyubiru & 318 & 4.42 & 299 & 4.32 & 617 & 4,37 \\
8 & Jambu & 288 & 4.00 & 304 & 4.39 & 592 & 4,19 \\
9 & Sumowono & 221 & 3.07 & 206 & 2.97 & 427 & 3,02 \\
10 & Ambarawa & 436 & 6.06 & 429 & 6.19 & 865 & 6,12 \\
11 & Bawen & 363 & 5.04 & 384 & 5.54 & 747 & 5,29 \\
12 & Bringin & 346 & 4.81 & 301 & 4.35 & 647 & 4,58 \\
13 & Bergas & 523 & 7.26 & 476 & 6.87 & 999 & 7,07 \\
14 & Pringapus & 359 & 4.99 & 383 & 5.53 & 742 & 5,25 \\
15 & Bancak & 163 & 2.26 & 169 & 2.44 & 332 & 2,35 \\
16 & Kaliwungu & 201 & 2.79 & 186 & 2.69 & 387 & 2,74 \\
17 & Ungaran Barat & 579 & 8.04 & 529 & 7.64 & 1.108 & 7,84 \\
18 & Ungaran Timur & 456 & 6.33 & 493 & 7.12 & 949 & 6,72 \\
19 & Bandungan & 424 & 5.89 & 441 & 6.37 & 865 & 6,12 \\
\hline & TOTAL & 7.200 & 100,00 & 6.927 & 100.00 & 14.127 & 100,00 \\
\hline
\end{tabular}

While the number of live births recorded at Semarang District Health Office in 2016 was 13,328 people. 
Table 2

Number of Birth Rates in 2016

\begin{tabular}{clcccccc}
\hline \multirow{2}{*}{ No } & \multirow{2}{*}{ Sub-Districts } & \multicolumn{2}{c}{ Men } & \multicolumn{2}{c}{ Women } & \multicolumn{2}{c}{ Total } \\
\cline { 2 - 7 } & & $\mathrm{n}$ & $\%$ & $\mathrm{n}$ & $\mathrm{\%}$ & $\mathrm{n}$ & $\%$ \\
\hline 1 & Getasan & 326 & $4,76 \%$ & 334 & $5,16 \%$ & 660 & $4,95 \%$ \\
2 & Tengaran & 483 & 7,055 & 433 & $6,69 \%$ & 916 & $6,87 \%$ \\
3 & Susukan & 277 & $4,04 \%$ & 284 & $4,39 \%$ & 561 & $4,21 \%$ \\
4 & Suruh & 509 & $7,43 \%$ & 269 & $4,15 \%$ & 778 & $5,84 \%$ \\
5 & Pabelan & 285 & $4,16 \%$ & 325 & $5,02 \%$ & 610 & $4,58 \%$ \\
6 & Tuntang & 475 & $6,93 \%$ & 441 & $6,81 \%$ & 916 & $6,87 \%$ \\
7 & Banyubiru & 313 & $4,57 \%$ & 298 & $4,60 \%$ & 611 & $4,58 \%$ \\
8 & Jambu & 277 & $4,04 \%$ & 264 & $4,08 \%$ & 541 & $4,06 \%$ \\
9 & Sumowono & 212 & $3,09 \%$ & 195 & $3,01 \%$ & 407 & $3,05 \%$ \\
10 & Ambarawa & 471 & $6,87 \%$ & 434 & $6,70 \%$ & 905 & $6,79 \%$ \\
11 & Bawen & 334 & $4,87 \%$ & 335 & $5,17 \%$ & 669 & $5,02 \%$ \\
12 & Bringin & 321 & $4,68 \%$ & 309 & $4,77 \%$ & 630 & $4,73 \%$ \\
13 & Bergas & 468 & $6,83 \%$ & 395 & $6,10 \%$ & 863 & $6,48 \%$ \\
14 & Pringapus & 362 & $5,28 \%$ & 342 & $5,28 \%$ & 704 & $5,28 \%$ \\
15 & Bancak & 162 & $2,36 \%$ & 163 & $2,52 \%$ & 325 & $2,44 \%$ \\
16 & Kaliwungu & 163 & $2,38 \%$ & 188 & $2,90 \%$ & 351 & $2,63 \%$ \\
17 & Ungaran Barat & 533 & $7,78 \%$ & 557 & $8,60 \%$ & 1.090 & $8,18 \%$ \\
18 & Ungaran Timur & 471 & $6,87 \%$ & 487 & $7,52 \%$ & 958 & $7,19 \%$ \\
19 & Bandungan & 411 & $6,00 \%$ & 422 & $6,52 \%$ & 833 & $6,25 \%$ \\
\hline & TOTAL & 6.853 & $100,00 \%$ & 6.475 & $100,00 \%$ & 13.328 & $100,00 \%$ \\
\hline
\end{tabular}

Based on the data above shows that the birth rate of babies in Semarang District decreased to 13,328 newborns in 2016 consisting of 6,853 male babies and 6,475 female babies, which originally in 2015 amounted to 14,127 newborns. With the highest number of births, there are 1,090 babies in West Ungaran District and 325 babies in Bancak District.

With the decrease in the number of baby births in Semarang Regency, it cannot be separated from the Government's role that can be said to be successful in carrying out programs made one of them through family planning programs so that the increase in population can be overcome. As well as being inseparable from the role of other figures who helped carry out this family planning program and also the most important role of the community from 19 subdistricts spread in Semarang District, resulting in a decrease in the number of baby births by 799 people. 


\section{FACTORS IN TACKLING POPULATION CONTROL THROUGH FAMILY PLANNING PROGRAMS IN SEMARANG REGENCY}

\section{SUPPORTING FACTORS IN TACKLING POPULATION CONTROL THROUGH FAMILY PLANNING PROGRAMS IN SEMARANG REGENCY}

In the implementation of the family planning program, of course there are factors that support it when the program is carried out. The supporting factors are as follows:

a. The existence of regional government organizations

In implementing the family planning program, it is necessary to have a role to carry it out. Which in Semarang Regency is the Office of Women's Empowerment, Child Protection and Family Planning which was originally named the Family Planning and Women's Empowerment Agency has a role in implementing programs that have been created by the government and delivered and applied directly to the community.

b. There is support for contraception

The success of the family planning program in Semarang Regency cannot be separated from the support of contraceptive devices provided by the National Population Planning Board (BKKBN). These contraceptives include a combination of progestin and estrogen birth control pills, IUD birth control pills, and progestin birth control pills.

c. Reliable medical staff

The role of reliable medical personnel namely doctors, midwives and nurses is very influential in the success of the family planning program undertaken. Without the role of medical staff the government program that has been created will not run properly. There is a need for cooperation between the government and medical personnel in order to reduce the high population growth in Semarang Regency.

d. The existence of data and reporting systems that are sustainable.

Data collection and reporting are important factors in the success of a program being implemented. With the data collection we can know the shortcomings and progress regarding a program that is being run. In addition, the presence of data collection and reporting systems makes it easy for each government agency to collaborate with other agencies and related parties. For this reason, it is very important to have continuous data collection and reporting. 


\section{INHIBITING FACTORS IN OVERCOMING POPULATION CONTROL THROUGH FAMILY PLANNING PROGRAMS IN SEMARANG REGENCY}

In its implementation there are not only factors supporting the implementation of the family planning program in order to create population control, but there are also inhibiting factors in its implementation. The inhibiting factors are:

a. Not all people have accepted the family planning program

Indonesian people, especially in Semarang Regency, are still many who do not want to accept the family planning program due to the culture of society that is still strongly embedded in each individual community, of which there are still many who assume "many children have a lot of luck".

b. Limited human resources

The number of human resources assigned is still small, where family planning field officers (PLKB), namely civil servants referred by the PP, PA, and KB Office as well as village cadres, are still many who are not willing to implement family planning programs made by the Government.

c. Its facilities and infrastructure are not yet optimal in function

Inadequate function of the facilities and infrastructure available in each village such as the lack of minimal facilities to implement family planning programs so that the implementation of family planning programs is hampered.

d. Funds released from the regional budget are not optimal

Funding released from the state budget is often not fully optimal so that whether the program has been made by the government has significant results or not. For this reason, the management of funds from the State Budget must be carried out in a better and planned manner so that the impact can be truly felt.

\section{CONCLUSION}

Based on the results of research and discussion that has been described previously, it can be concluded about the problems that implementation of increasing population control through the family planning program in Semarang Regency is carried out regulations from the central level to the field. The role of the government is to provide socialization and coordination in the implementation of family planning. In addition, the government communicates by providing information and education to the public. The success of the family planning program cannot be separated from the participation of the community itself. Can be seen until the end of 2016 the implementation of the family planning program carried out by the Office of PP, PA, and $\mathrm{KB}$ in collaboration with various parties runs very well. Where can be seen from the reduction in the number of baby births from 2015 the number of births was 14,127 consisting of baby boys and baby girls spread from 19 districts in Semarang Regency. And the number of babies born in 2016 was 13,328 consisting of boys and girls from 19 districts in Semarang Regency. Supporting factors in the implementation of family 
planning programs are the existence of regional apparatus organizations; support for contraception; reliable medical personnel; the existence of data and reporting systems that are sustainable. In addition to the supporting factors that support the success of the program being run, there are obstacles encountered when implementing the KB program in order to create population control, among others not all communities have accepted the family planning program; limited human resources; facilities and infrastructure that are not yet optimal in function; funds disbursed from the regional budget are not optimal.

\section{REFERENCES}

Ataullahjan, A., Mumtaz, Z., \& Vallianatos, H. (2019). Family planning in Pakistan: A site of resistance. Social Science and Medicine, 230(November 2018), 158-165. https://doi.org/10.1016/j.socscimed.2019.04.021

Asshiddiqie, J. (2005) Hukum Tata Negara dan Pilar-Pilar Demokrasi. Jakarta: Konstitusi Press.

Bang, K. S., Chae, S. M., Lee, I., Yu, J., \& Kim, J. (2018). Effects of a Community Outreach Program for Maternal Health and Family Planning in Tigray, Ethiopia. Asian Nursing Research, 12(3), 223-230. https://doi.org/10.1016/j.anr.2018.08.007

Barroso, C. (2015). Family Planning Programs: Feminist Perspectives. In International Encyclopedia of the Social \& Behavioral Sciences: Second Edition (Second Edi, Vol. 8). https://doi.org/10.1016/B978-0-08-097086-8.31030-3

Brown, W., Ahmed, S., Roche, N., Sonneveldt, E., \& Darmstadt, G. L. (2015). Impact of family planning programs in reducing high-risk births due to younger and older maternal age, short birth intervals, and high parity. Seminars in Perinatology, 39(5), 338-344. https://doi.org/10.1053/j.semperi.2015.06.006

Brunson, J. (2019). Tool of economic development, metric of global health: Promoting planned families and economized life in Nepal. Social Science and Medicine, (December 2018), 0-1. https://doi.org/10.1016/j.socscimed.2019.05.003

Carter, E. D. (2018). Population control, public health, and development in mid twentieth century Latin America. Journal of Historical Geography, 62, 96-105. https://doi.org/10.1016/j.jhg.2018.03.012

Catley-Carlson, M. (1997). Implementing family planning programs in developing countries: Lessons and reflections from four decades of Population Council experience. International Journal of Gynecology and Obstetrics, 58(1), 101-106. https://doi.org/10.1016/S0020-7292(97)02858-0

Eslami, M., \& D'Arcangues, C. (2016). Aiming for quality in Iran's national family planning program - Two decades of sustained efforts. Contraception, 93(3), 209215. https://doi.org/10.1016/j.contraception.2015.11.013

Eva, G., Quinn, A., \& Ngo, T. D. (2015). Vouchers for family planning and sexual and reproductive health services: A review of voucher programs involving Marie Stopes International among 11 Asian and African countries. International Journal of Gynecology and Obstetrics, 130, El5-E20. https://doi.org/10.1016/j.ijgo.2015.06.023 
Fischer, S., Royer, H., \& White, C. (2018). The impacts of reduced access to abortion and family planning services on abortions, births, and contraceptive purchases. Journal of Public Economics, 167, 43-68. https://doi.org/10.1016/j.jpubeco.2018.08.009

Garney, W. R., Wilson, K., Nelon, J. L., Hays, C., Garcia, K. M., Muraleetharan, D., ... McLeroy, K. (2019). Understanding innovation in health program planning and development. Evaluation and Program Planning, 73, 226-231. https://doi.org/10.1016/j.evalprogplan.2019.02.001

Guiahi, M., Cortland, C., Graham, M. J., Heraty, S., Lukens, M., Trester, M., ... Kenton, K. (2011). Addressing OB/GYN family planning educational objectives at a faithbased institution using the TEACH program. Contraception, 83(4), 367-372. https://doi.org/10.1016/j.contraception.2010.07.012

Johnson, D., Juras, R., Riley, P., Chatterji, M., Sloane, P., Choi, S. K., \& Johns, B. (2017). A randomized controlled trial of the impact of a family planning mHealth service on knowledge and use of contraception. Contraception, 95(1), 90-97. https://doi.org/10.1016/j.contraception.2016.07.009

Kelsen, H. (2010). Teori Umum Hukum dan Negara: Dasar-Dasar Ilmu Hukum Normatif Sebagai Ilmu Hukum Deskriptif-Empirik. Bandung: Bee Media Indonesia.

Loyola Briceno, A. C., Kawatu, J., Saul, K., DeAngelis, K., Frederiksen, B., Moskosky, S. B., \& Gavin, L. (2017). From theory to application: using performance measures for contraceptive care in the Title X family planning program. Contraception, 96(3), 166-174. https://doi.org/10.1016/j.contraception.2017.06.009

Masiano, S. P., Green, T. L., Dahman, B., \& Kimmel, A. D. (2019). The effects of community-based distribution of family planning services on contraceptive use: The case of a national scale-up in Malawi. Social Science \& Medicine, 238(August 2018), 112490. https://doi.org/10.1016/j.socscimed.2019.112490

McCarthy, A. S. (2019). Intimate partner violence and family planning decisions: Experimental evidence from rural Tanzania. World Development, 114, 156-174. https://doi.org/10.1016/j.worlddev.2018.09.027

Miller, E., Tancredi, D. J., Decker, M. R., McCauley, H. L., Jones, K. A., Anderson, H., ... Silverman, J. G. (2016). A family planning clinic-based intervention to address reproductive coercion: A cluster randomized controlled trial. Contraception, 94(1), 58-67. https://doi.org/10.1016/j.contraception.2016.02.009

Miller, G., \& Babiarz, K. S. (2015). Family Planning: Program Effects. In International Encyclopedia of the Social \& Behavioral Sciences: Second Edition (Second Edi, Vol. 8). https://doi.org/10.1016/B978-0-08-097086-8.31036-4

Mohan, V., \& Shellard, T. (2014). Providing family planning services to remote communities in areas of high biodiversity through a Population-HealthEnvironment programme in Madagascar. Reproductive Health Matters, 22(43), 93103. https://doi.org/10.1016/S0968-8080(14)43766-2

Moleong, L.J. (2012). Metode Penelitian Kualitatif. Bandung: PT Remaja Rosdakarya.

Nalwadda, G., Namutebi, M., \& Volgsten, H. (2019). Health care providers' perceptions of family planning and contraception education for adolescents in Kampala, Uganda - A qualitative study. Sexual and Reproductive Healthcare, 21(May), 


\section{5-20. https://doi.org/10.1016/j.srhc.2019.05.001}

Pusat Pendidikan dan Latihan BKKBN. (1980). Keluarga Berencana dan Hubungannya Dengan Kesejahteraan Keluarga. Jakarta: BKKBN

Republic of Indonesia. (1945). Constitution of Indonesia of 1945, Undang - Undang Dasar 1945

Republic of Indonesia. (2009). Law Number 52 of 2009 concerning Population

Development and Family Development, Undang-Undang Nomor 52 Tahun 2009 Tentang

Perkembangan Kependudukan dan Pembangunan Keluarga

Republic of Indonesia. (2014). Government Regulation No. 87 of 2014 concerning

Development of Population and Family Development, Family Planning and

Family Information Systems, Peraturan Pemerintah No. 87 Tahun 2014 Tentang

Perkembangan Kependudukan dan Pembangunan Keluarga, Keluarga Berencana dan Sistem Informasi Keluarga

Republic of Indonesia. (2014). Regional Regulation of Central Java Province No. 6 of

2013 concerning Population Control and Family Planning Organization, Peraturan

Daerah Provinsi Jawa Tengah No. 6 Tahun 2013 tentang Pengendalian Penduduk dan

Penyelenggaraan Keluarga Berencana

Ritonga, A. et.al. (2001). Kependudukan dan Lingkungan Hidup. Jakarta: Fakultas Ekonomis Universitas Indonesia.

Rogers, J., Silva, S., Benatar, S., \& Briceno, A. C. L. (2018). Family Planning Confidential: A Qualitative Research Study on the Implications of the Affordable Care Act. Journal of Adolescent Health, 63(6), 773-778. https://doi.org/10.1016/j.jadohealth.2018.06.020

Segrott, J., Murphy, S., Rothwell, H., Scourfield, J., Foxcroft, D., Gillespie, D., ... Moore,

L. (2017). An application of Extended Normalisation Process Theory in a randomised controlled trial of a complex social intervention: Process evaluation of the Strengthening Families Programme (10-14) in Wales, UK. SSM - Population Health, 3(June 2016), 255-265. https://doi.org/10.1016/j.ssmph.2017.01.002

Shidarta, S., \& Irianto, S. (2011). Metode Penelitian Hukum Konstelasi dan Refleksi. Jakarta: Yayasan Pustaka Obor Indonesia.

Soekanto, S. (1986). Pengantar Penelitian Hukum. Jakarta : UI-Press.

Sonalkar, S., Mody, S., \& Gaffield, M. E. (2014). Outreach and integration programs to promote family planning in the extended postpartum period. International Journal of Gynecology and Obstetrics, 124(3), 193-197. https://doi.org/10.1016/j.ijgo.2013.09.021 Suratman, H. P.D. (2013). Metode Penelitian Hukum. Bandung: Alfabeta.

Tran, N. T., Seuc, A., Coulibaly, A., Landoulsi, S., Millogo, T., Sissoko, F., ... Kouanda, S. (2019). Post-partum family planning in Burkina Faso (Yam Daabo): a two group, multi-intervention, single-blinded, cluster-randomised controlled trial. The Lancet Global Health, 7(8), ello9-ell17. https://doi.org/10.1016/S2214-109X(19)30202-5

Traxler, S. A., Chavez, V., Hadjiliadis, D., Shea, J. A., Mollen, C., \&e Schreiber, C. A. (2019). Fertility considerations and attitudes about family planning among women with cystic fibrosis. Contraception, (xxxx). https://doi.org/10.1016/j.contraception.2019.05.005 
Wang, C. (2012). History of the Chinese Family Planning program: 1970-2010. Contraception, 85(6), 563-569. https://doi.org/10.1016/j.contraception.2011.10.013

Wang, X., \& Zhang, J. (2018). Beyond the Quantity-Quality tradeoff: Population control policy and human capital investment. Journal of Development Economics, 135, 222-234. https://doi.org/10.1016/j.jdeveco.2018.04.007

Woo, C. J., Alamgir, H., \& Potter, J. E. (2016). Women's experiences after Planned Parenthood's exclusion from a family planning program in Texas. Contraception, 93(4), 298-302. https://doi.org/10.1016/j.contraception.2015.12.004

Yarger, J., Decker, M. J., Campa, M. I., \& Brindis, C. D. (2017). Rural-Urban Differences in Awareness and Use of Family Planning Services Among Adolescent Women in California. Journal of Adolescent Health, 60(4), 395-401. https://doi.org/10.1016/j.jadohealth.2016.10.016

Yuliyanto, M.F. (2009). Dualisme Penenlitian Hukum Normatif \& Empiris. Yogyakarta: Pustaka Pelajar.

Zhang, W.-H., Li, J., Che, Y., Wu, S., Qian, X., Dong, X., ... Temmerman, M. (2017). Effects of post-abortion family planning services on preventing unintended pregnancy and repeat abortion (INPAC): a cluster randomised controlled trial in 30 Chinese provinces. The Lancet, 390, S29. https://doi.org/10.1016/s0140$6736(17) 33167-7$ 


\section{QUOTE}

Population growth is straining the Earth's resources to the breaking point, and educating girls is the single most important factor in stabilizing that.

That, plus helping women gain political and economic power and safeguarding their reproductive rights.

\section{Al Gore}

